\title{
Ratio Analysis of J Sainsbury plc Financial Performance between 2015 and 2018 in Comparison with Tesco and Morrisons
}

\author{
Lin Guo ${ }^{*}$, Zhen Wang \\ ${ }^{1}$ Business School, Newcastle University, New Castle upon Tyne, UK \\ ${ }^{2}$ Research Institute of Foreign Languages, Beijing Foreign Studies University, Beijing, China \\ Email: ^guolinnbu@163.com,wangzhenbfs@163.com
}

How to cite this paper: Guo, L. and Wang, Z. (2019) Ratio Analysis of J Sainsbury plc Financial Performance between 2015 and 2018 in Comparison with Tesco and Morrisons. American Journal of Industrial and Business Management, 9, 325-341. https://doi.org/10.4236/ajibm.2019.92022

Received: January 17, 2019

Accepted: February 24, 2019

Published: February 27, 2019

Copyright $\odot 2019$ by author(s) and Scientific Research Publishing Inc. This work is licensed under the Creative Commons Attribution International License (CC BY 4.0). http://creativecommons.org/licenses/by/4.0/

\begin{abstract}
Financial ratio analysis is an analysis of a company's financial statements, and it is vital for identifying negative and positive trends of a business over time. This article sets out to provide a detailed analysis of the financial performance of J Sainsbury plc and compare it with the performance of Tesco and Morrisons. From the data analysis, it can be shown that from 2015, the financial performance of J Sainsbury plc is improving with an increasing trend in its sales revenue and gross margin, while there is a decreasing trend in its return on assets (ROA), operating profit, pretax profit margin, finance cost and net profit. Compared to the other two companies in the same industry like Tesco and Morrisons, the performance of J Sainsbury plc is somewhat satisfactory. Finally, some recommendations on financial aspects, business environment and strategies are offered to enhance J Sainsbury plc's performance and promote its sustainable development.
\end{abstract}

\section{Keywords}

Profitability, Liquidity, Solvency, Operational Efficiency, J Sainsbury plc

\section{Introduction}

Ratio analysis or account analysis is an effective way to estimate and compare the financial performance of a company in a particular year with that of other years and other companies in the same industry. Due to the fierce competition in retail superstore grocery market in United Kingdom (UK), it is of necessity to analyze the strengths, weaknesses, opportunities and threats of each company in great detail to successfully seize more potential chances and be a winner in the 
market.

J Sainsbury plc is accredited as one of the oldest and most prominent retail companies in UK. Initially opened as a single grocery store, Sainsbury's gradually expanded to have its own-brand preserved meats, which were produced in-house and delivered to numerous locations throughout London, including a suburban branch in Croydon selling "high class provisions" to a more affluent base of customers. In 1922, it was incorporated as J Sainsbury Ltd. After enduring the Second World War, Sainsbury's began to recover during the postwar period and was a pioneering figure in the introduction of a self-service shopping system into its stores, which led to a relative revolution in the manner in which customers interact with their supermarkets. The style of shopping was championed by Sainsbury's in this time, which witnessed a transition of norm from full-service counters to the shops like those we use nowadays. Prior to this, shoppers had exclusively purchased groceries through direct interaction with a shop assistant, who would retrieve any requested products from storage. Allowing customers to browse through aisles of stacked goods had thus far been a rarity. This theme of innovation has repeated throughout the history of Sainsbury's, perhaps most notably with its claim to being the first grocery retailer to computerize its stock distribution in 1961. During 1970 to 1999, Sainsbury's focused on its expansion across the country. In February 1997, Sainsbury's launched its banking arm Sainsbury's Bank as a joint venture with Bank of Scotland, which became wholly-owned by J Sainsbury plc in 2014. In the following years, Sainsbury's diversified further into several other brands in varying sectors. In the early 2000s, the in-store fashion brand $\mathrm{Tu}$ was launched. More recently, the purchase of Argos, a catalogue retailer, and Habitat, a household furnishings retailer, were completed in 2016. Following these acquisitions, the board of Sainsbury's announced the proposed combination with Walmart's Asda, which would, if completed, create the largest retailer of groceries in UK. Nowadays, under the lead of current CEO Mike Coupe, Sainsbury's has developed into a multi-segmental company headquartered in London. The retailing segment contains 608 Sainsbury's supermarkets, 815 convenience stores, more than 844 Argos (191 in Sainsbury's supermarket) and 16 Habitat, and the financial segment is mostly known as Sainsbury's Bank plc. It also has joint ventures in real estate. The current revenue of the group is $£ 28,456 \mathrm{~m}$, with a basic EPS of $£ 13.3 p$.

This article sets out to analyze the financial performance of Sainsbury's and compare it with two of its most prominent competitors to shed light on how big businesses run their financial activities in today's competitive economy. The first one selected for the purposes of analysis is Tesco PLC. which was founded in London in 1919 by Jack Cohen. In 1947, after the expansions in the south of England, the company was incorporated. Nowadays, Tesco has become a global brand mainly operated in the UK, Thailand, Malaysia, India, Czech Republic, China and Hungary. Overall, there are more than 6800 Tesco stores. The major 
operating of Tesco includes retail, such as supermarkets, and Tesco Bank provides financial services in the UK. The year-end group revenue is $£ 57,491 \mathrm{~m}$, with a basic EPS at $£ 14.77$ p. Wm Morrison Supermarkets plc is another powerful rival of Sainsbury's. Morrisons has a reputation for selling higher quality food products at competitive prices, and has a unique store design at larger locations featuring the "Market Street" concept, wherein the supermarket building is fitted to resemble a typical English small-town high street. This is achieved through such motifs as the arrangement of the in-store butcher, baker and fishmonger departments in a manner reminiscent of a traditional English market, and a prominent clock tower built into the entry façade of most such supermarkets. Morrisons' strategy is largely specialized in its fresh food retailing. Over half of the company's foods are manufactured by its own factories, which guarantees customers with freshly made food every day. The online shopping aspect of the business has also been increasing in popularity in recent years. The current sales revenue of Morrisons is $£ 17,262 \mathrm{~m}$, and the basic EPS is $£ 13.30 \mathrm{p}$.

Researchers have made attempts to analyze the financial performance of Sainsbury's, and compared its performance with that of other companies in the same industry. Azeez (2015) made a critical capital investment appraisal of Sainsbury's based on its financial annual report and financial statements for the year 2013, providing an insight into its capital investment decision [1]. There are also some comparative studies concentrating on the financial performance of Sainsbury's and other companies. Applying an integrated financial appraisal framework, CORE (context, overview, ratios and evaluation), Moon and Bates [2] analyzed and appraised the performance of Tesco and J. Sainsbury's. Sales data of Tesco and Sainsbury's between 1994 and 1996 were analyzed to interpret how Tesco overtook Sainsbury's in the supermarket, demonstrating that the greater physical expansion and the larger number of customers can contribute to Tesco's sales growth [3]. Zhou [4] analyzed the quality and usefulness of financial statements of J Sainsbury plc in close reference to qualitative characteristics of financial information and further compared the financial statements of J Sainsbury plc with those of Tesco PLC. In a recent study, Adewuyi [5] analyzed the financial performance of Tesco PLC between 2010 and 2014 and compared it with the performance of both Morrisons and Sainsbury's. It is predicted that Tesco PLC may suffer loss in the near future, and, hence, some suggestions were made to improve its performance.

Previous studies have focused on the financial ratio results of Sainsbury's as well as its comparison with other businesses. However, no research has thus far been conducted on the financial performance of Sainsbury's and the comparison of it with other big companies in most recent time (2015-2018). Therefore, it is of significance to conduct a ratio analysis of the financial performance of $J$ Sainsbury plc from 2015 to 2018 and compare it with the performance of Tesco and Morrisons. Carrying out such an analysis can pinpoint these companies' strengths and weaknesses, which in turn, can offer useful insight for business 
decision-making for these companies as well as other businesses. We have chosen Sainsbury's, Tesco and Morrisons because they are prominent retail companies in the UK. Moreover, an analysis of these companies' financial Annual Report and Financial Statements for recent years (i.e., 2015-2018) can help people gain insight into how big businesses run their financial activities in today's competitive economy.

The goal of this article is to critically analyze the financial ratio results of Sainsbury's and compare them with those of Tesco and Morrisons. We will utilize the ratio analysis technique to examine their financial performance. Firstly, the results of a comparative analysis of the profitability, liquidity, solvency, operational efficiency and common size of the three companies will be presented. This is followed by a trend analysis of Sainsbury's to show the pattern of its financial performance over the years 2016 to 2018. In addition, some recommendations on financial aspects, business environment and strategies will be offered to enhance J Sainsbury plc's performance and promote its sustainable development. Finally, limitations of the study and suggestions for future work will be presented.

\section{Research Methodology}

The data showing the financial performance of Sainsbury's, Tesco and Morrisons between 2016 and 2018 was majorly derived from each company's published financial statements, which can be easily downloaded from their official websites. This paper covers accounting data from year 2015 to 2018. The fiscal year of J Sainsbury plc is 52 weeks from March of the previous year to the March of following year. As for Tesco PLC, the fiscal year is 52 weeks from the end of February to the following February. Morrisons plc defined its financial year as 53 weeks from the beginning of February to the next beginning of February. In order to draw a complete picture of the company, there are four major financial abilities of Sainsbury's calculated; they are profitability, liquidity, solvency and operational efficiency. The representative ratios for measuring the company's profitability are gross margin and return on assets, based on net income for the year. The liquidity will be measured by calculating quick ratio and current ratio, which focuses on the ability of paying debts. As the opposite of liquidity, solvency ratio will help us find out the ability of the business to pay off its longer term debts, such as pensions. Operating efficiency consists of asset turnover and inventory turnover. J Sainsbury plc financial performance has been analyzed concerning profitability, liquidity, solvency, operational efficiency, common size analysis, trend analysis as well as segmental financial analysis. The financial performance of J Sainsbury plc has been further compared with that of both Tesco and Morrisons.

The trend analysis which enables us to know what is happening within the financials of Sainsbury's will also be conducted. Moreover, all operating segments of Sainsbury's financial performance, such as retails and financial services, will 
be compared to the group accounts. When calculating the ratios for Tesco PLC, the column of "exceptional items" is excluded for more accurate results. Also, restated accounting figures are used to follow the prudence concept. Data will be presented in the form of graphs and percentages.

\section{Results and Discussion}

\subsection{Profitability}

Profitability measures a company's ability of generating profits of spending a certain amount of associated expenses. Normally, the higher the ratio(s), the better the business is at generating earnings. The gross margin and return on assets will be analyzed.

\subsubsection{Gross Margin}

Gross margin is one of valid index to measure profitability ratio which equals to gross profit (revenues - cost of goods sold) divided by revenues. Usually, it represents the portion of each pound of sales revenue, and can be retained as gross profit [6]. For example, the gross margin of Sainsbury's is $5.1 \%$ for the year of 2015/16. Therefore, Sainsbury's has retained $£ 0.051$ from each pound of revenues. In general, managers and investors would prefer a higher gross margin.

As we can see from Figure 1, J Sainsbury plc has generated most significant gross profit related to its production cost during the past 3 years. Although the cost of sales is increasing, revenues of the company have grown faster than the cost of sale, along with significant cost savings strategies, which contribute to the good results. Its rival Tesco has the second best progress, with the constant decrease in the cost of sales and increase in revenues each year. However, Morrisons has suffered a constant drop in revenues from $£ 761 \mathrm{~m}$ to $£ 604 \mathrm{~m}$. Therefore, even if Morrisons tried to cut the costs, the gross margin would not recover.

\subsubsection{Return on Assets (ROA)}

ROA is calculated as net income/total assets at the end of the period. It shows how effectively the investors convert the assets into returns [7]. This is one of

\section{Gross Margin \%}

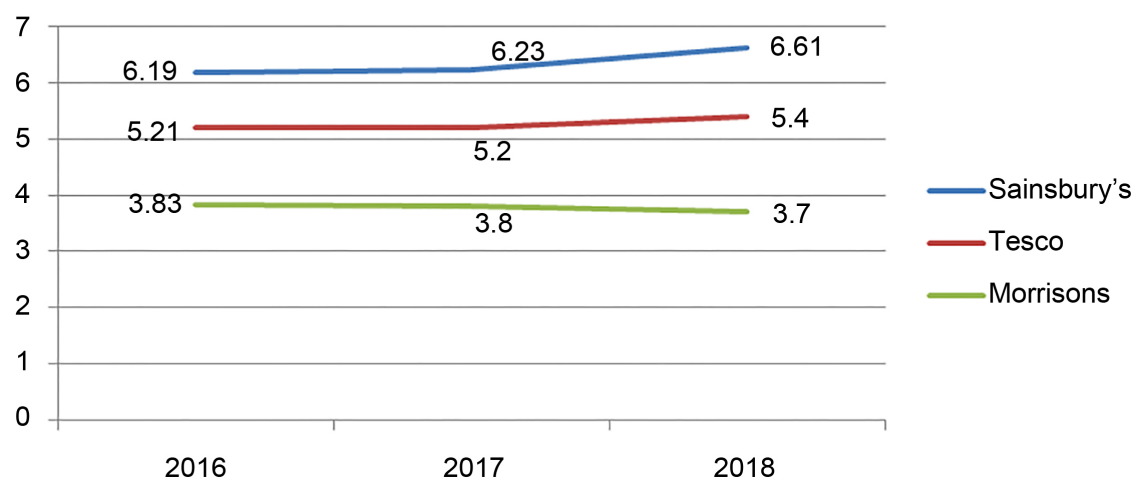

Figure 1. Gross margins of Sainsbury's compared with Tesco and Morrisons. 
essential performance benchmark for retail companies, since they rely heavily on selling inventories [7].

Although Sainsbury's has the best gross margin, its performance in ROA is not well, especially since it shows a trend of decreasing from approximately 2.77 pence to 1.4 pence from year 2017 to 2018 in Figure 2. This can be found through the decreasing net income every year; and the firm has been spending significant amounts on acquiring assets at the same time. On the contrary, its major competitors are generating increasing return on their assets. Particularly, Morrisons is generating the most returns, as its ROA line lays at the top of the chart.

\subsection{Liquidity}

Liquidity describes how fast a business can pay off liabilities regarding its current assets. Supermarkets such as Sainsbury's, Tesco and Morrisons tend to have liquidity ratio lower than 1 , since they are very likely to have low level of trade receivables and cash, medium level of inventories but high receivables. What investors would find most salient with which to pay attention is the trend, and they should also watch out for the trend of other competitive companies.

\subsubsection{Current Ratio}

Current ratio shows a firm's ability of paying its financial obligations by calculating the proportion of its current assets to current liabilities. The higher the current ratio, the company is more likely to generate and dispose more current assets to pay off its debts [8].

As illustrated in Figure 3, Tesco maintains the best current ratio at first glance, but Sainsbury's has performed better respective to relative size. The current ratio of Sainsbury's shows a trend of growth, while Tesco shows the opposite. This may be due to the increasing level of current assets and declining current liabilities. For example, there are more assets available for sale and more accounts receivables. The current ratio of Morrisons first shows a 0.07 unit drop and it has been improved in 2018 .

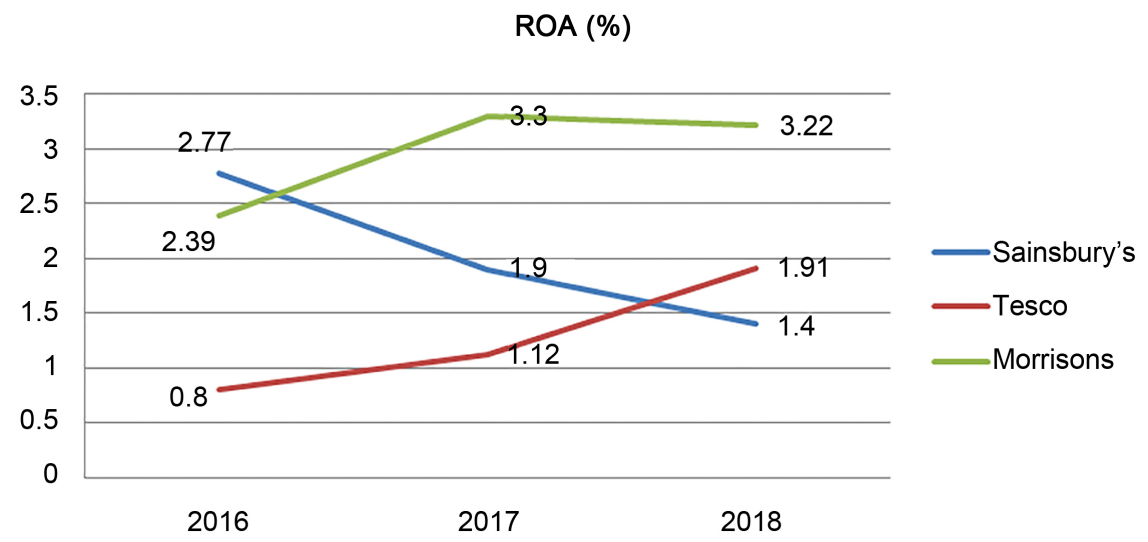

Figure 2. ROA of Sainsbury's compared with Tesco and Morrisons. 


\section{Current Ratio}

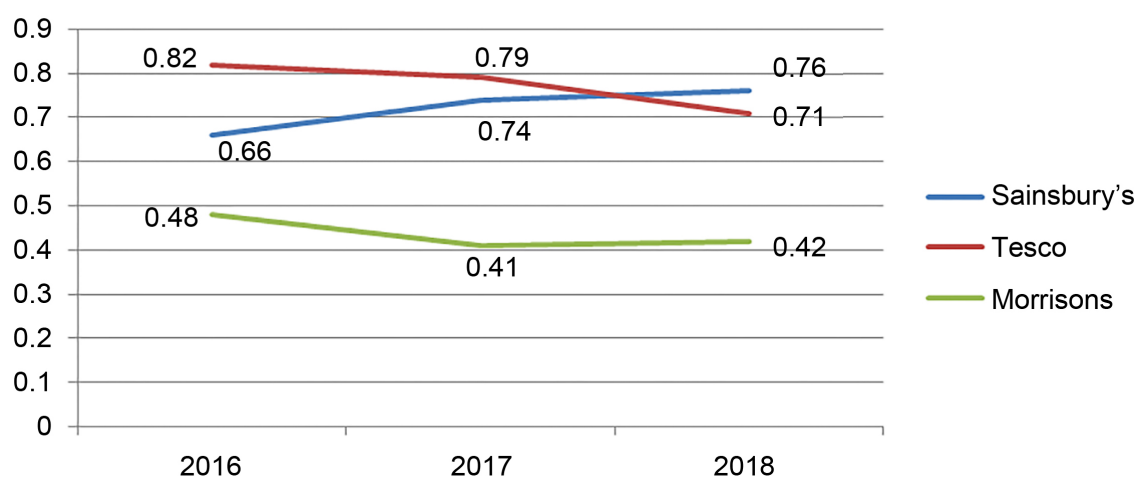

Figure 3. Current ratio of Sainsbury's compared with Tesco and Morrisons.

\subsubsection{Quick Ratio}

One of the short-term indicators for liquidity is quick ratio, which measures a company's ability in meeting short-term liabilities with its quick assets that can be converted into cash within 90 days [9]. Hence, the calculation of the ratio will subtract inventories from current assets, and then divide it by current liabilities, ${ }^{1}$ as inventories cannot be sold during a short term [9].

As shown in Figure 4, Sainsbury's quick ratio has been increasing smoothly, which may be a result of more available quick assets to cover its short-term debt; the liquidity position is becoming better. Particularly, in 2018, Sainsbury's quick ratio has reached the same level as Tesco at 0.59 , whereas Tesco's liquidity condition is getting worse every year. Nonetheless, Morrisons' quick ratio has not shown any noteworthy change, and it is relatively stable, around 0.2 to 0.3 .

\subsection{Solvency}

Contrary to liquidity, solvency represents a company's ability to pay off its long-term liabilities. It is essential to maintain solvency since it proves the ability of operating continuously in the future [10].

\subsubsection{Debt to Equity Ratio}

The first solvency ratio is debt to equity ratio (D/E ratio). It is calculated simply as total liabilities ${ }^{2}$ divided by total equity. It demonstrates how much liability is used by the business to finance its assets regarding to its equity [11]. A high D/E ratio could indicate that the company is financing its growth aggressively with debt, and it often associates with risk of fluctuations in earnings resulting from high finance costs [11].

As illustrated in Figure 5, Sainsbury's has a medium level of D/E ratio in comparison to Tesco and Morrisons, and it is the only one that shows an increase among these three companies. Based on the analysis, it can be inferred

${ }^{1}$ Here, the assets and liabilities held for sale are excluded from current assets and liabilities, because according to financial statements, the transactions completed in more than 90 days.

${ }^{2}$ Total liabilities equal to current liabilities plus non-current liabilities. 
Quick Ratio

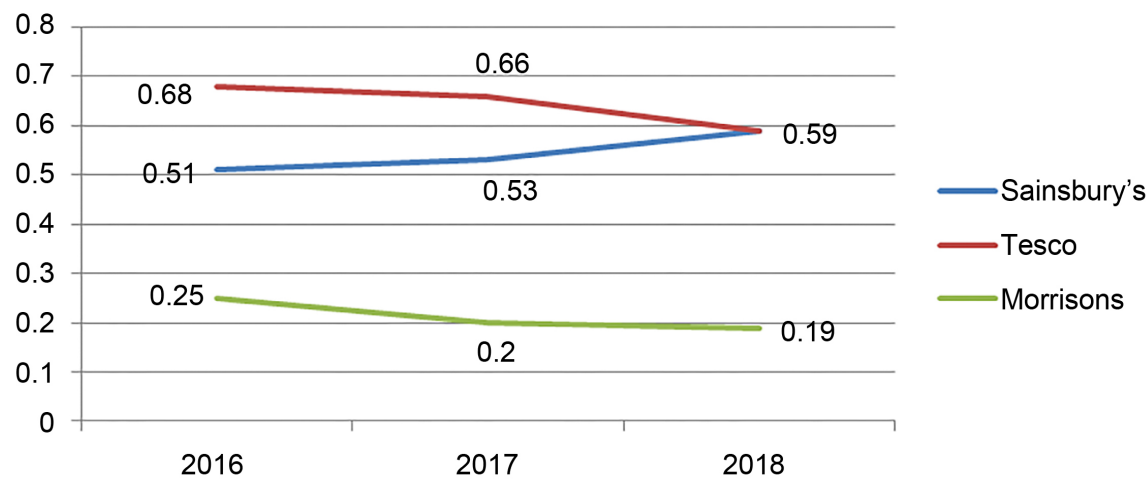

Figure 4. Quick ratio of Sainsbury's compared with Tesco and Morrisons.

D/E Ratio

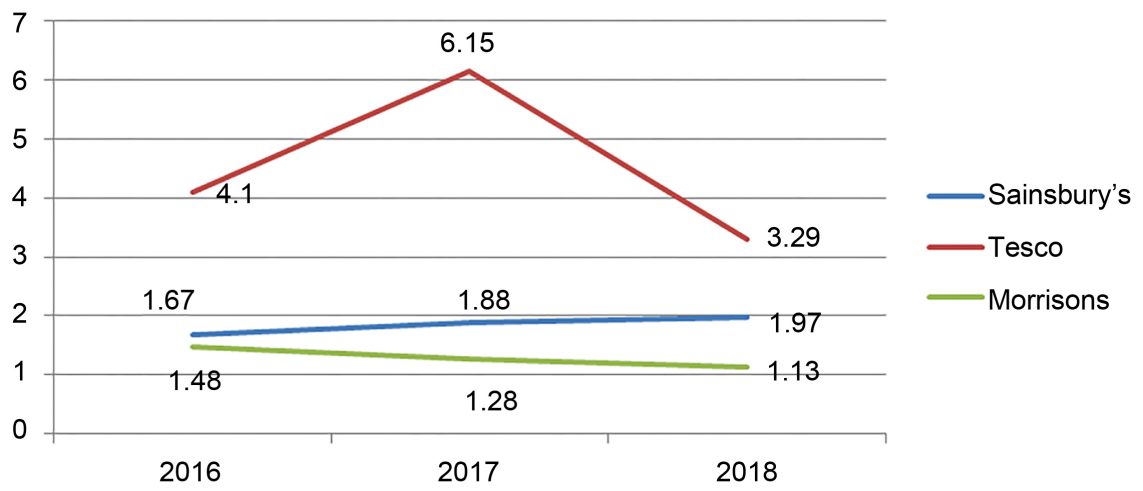

Figure 5. D/E ratio of Sainsbury's compared with Tesco and Morrisons.

that Sainsbury's is borrowing a lot for financing its expansion since 2016. Meanwhile, the total equity has also increased over time, which would slow down the growth of D/E ratio. As for the UK biggest retailer, Tesco has the highest financial risk according to D/E ratio, but its financial position is becoming better through generating more equity. Morrisons has the minimum D/E ratio which shows a decline, and it is probably resulted from an increasing total equity and decreasing liabilities.

\subsubsection{Total Debt to Total Assets}

This ratio is calculated by dividing a company's total liabilities to its total assets. Rather than equity, it indicates how a company is financing its assets by borrowing. According to this ratio, investors can know how the company has acquired and expanded its assets gradually. Therefore, they can assess whether the company can pay off its current liabilities and deliver the return they want [11]. Typically, the higher the ratio, the more risks the company would take in investing. A result less than 1 means there are more assets than debts in the company, and the financial obligations could be met by selling available assets [12].

Seen from Figure 6, the D/E ratio of the three companies is quite similar. 
Morrisons seems to be the least risky to be invested in, since the total debt occupies the least assets in relation to its operating size. Although there is an increase in the debt, however, Sainsbury's debt to assets ratio remains at a relatively stable level. This could be due to the fact that there is no big change in its liabilities or assets over time. The financial position of its biggest competitor, Tesco, is becoming stronger, with a cut in liabilities in 2018 (approximately $\mathfrak{£} 4846 \mathrm{~m}$ ).

\subsection{Operational Efficiency}

Operational efficiency measures the efficiency of a business generating profit from operational costs. The most representative ratio is inventory turnover ratio, since larger retailers, such as Sainsbury's, rely heavily on selling inventories.

\subsubsection{Asset Turnover}

Asset turnover measures how much sales or revenues a company can generate from every pound in assets. It is calculated as sales revenue divided by average total assets. ${ }^{3}$ Generally speaking, higher asset turnover is preferable. As for retail industry, the ratio often is relatively higher than other industries, by having high volumes of sales but relatively small bases of assets [13].

As Figure 7 shows, for every pound in assets, Morrisons has generated most earnings from utilizing its total assets during the last 3 years, followed by Sainsbury's and Tesco. Sainsbury's, especially its sales figure, shows a decline while it keeps an increasing trend in its total assets, such as inventories and trade receivables. Therefore, it may be concluded that the company is holding obsolete assets and lacks of efficient debt collection method. As for Morrisons, the increasing asset turnover might result from the increasing sales every year, because it is utilizing the assets better than Sainsbury's. As the biggest retailer in the UK, Tesco has a worse asset turnover relative to Morrisons, the much smaller retailer. It is possible that there are too many idle assets which need to be used.

Total debt to Total assets \%

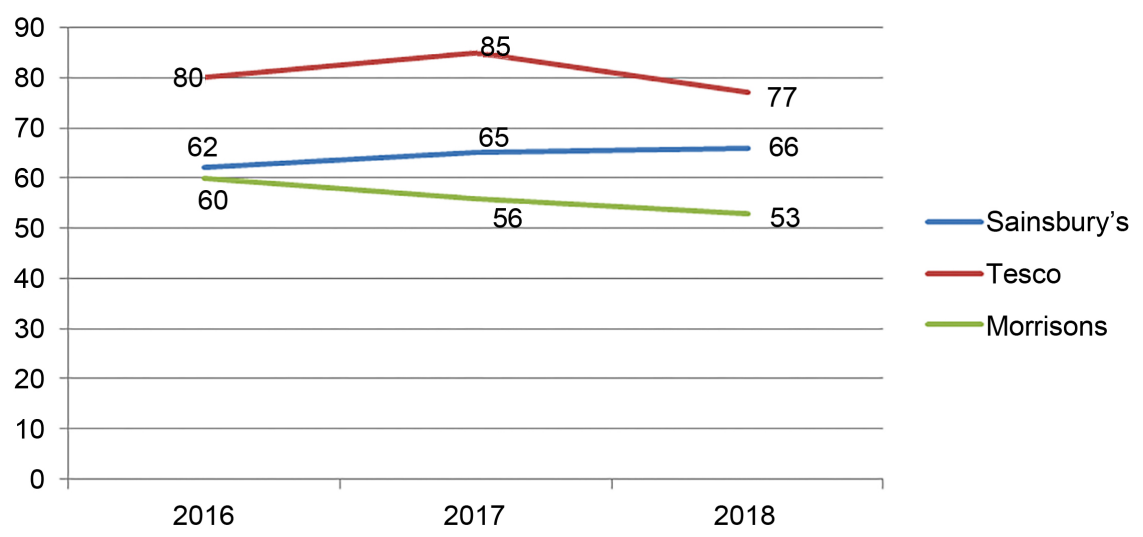

Figure 6. Total debt to total assets (\%) of Sainsbury's compared with Tesco and Morrisons.

${ }^{3}$ Average total assets equals to (total assets at the beginning of the period + total assets at the end of the period) $/ 2$. 


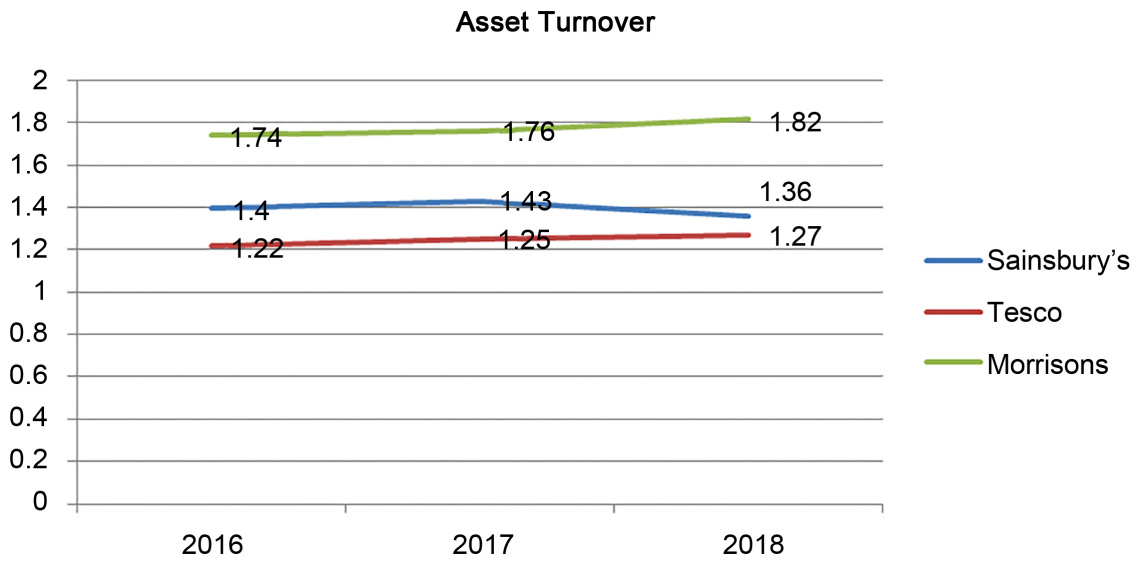

Figure 7. Asset turnover of Sainsbury's compared with Tesco and Morrisons.

\subsubsection{Inventory Turnover}

Inventory turnover measures how many times a company sells and replaces its stock during a period [14] [15]. It is calculated as: cost of goods sold/average inventory. ${ }^{4}$ It conveys how efficient the inventory management of the company is. Since the older inventory will become obsolete, a higher inventory ratio is better.

As shown in Figure 8, it can be seen that Morrisons replaces its inventory most frequently between 2016 and 2018. Although Sainsbury's has made more sales every year, the inventory turnover has decreased from 22 times to 15 times. This may indicate that the company overestimated the high demand of customers for purchasing too many goods, since the stock figure is showing a relatively fast growth [14]. Furthermore, its sales department may not operate properly since the sales did not match with inventory [14]. As for Tesco and Morrisons, their inventory turnover shows a similar increasing trend, which may arise from their stock level maintenance when sales grow steadily.

\subsection{Common Size Analysis}

Common size analysis is also known as vertical analysis, which provides an easier way for stakeholders to be acquainted with a company's financial statements [16]. A common size income statement (Table 1) is particularly useful, because it will show investors the factors that are dividing the profit via the \% of each line item of sales revenue (base figure). This will enable a comparison to its peer rivals. Also, by comparing the performance over time, it is more likely to disclose the financial trends.

The table shows that Sainsbury's cost of sales divides minimum profit, which leads to the higher gross margin compared to the other two peer companies, Tesco and Morrisons. Therefore, even though the operating expenses divide around $4 \%$ of sales, its operating profit margin (operating income divided by sales) is still the best.

${ }^{4}$ Average total inventories equals to (inventories at the beginning of the period + inventory at the end of the period) $/ 2$. 


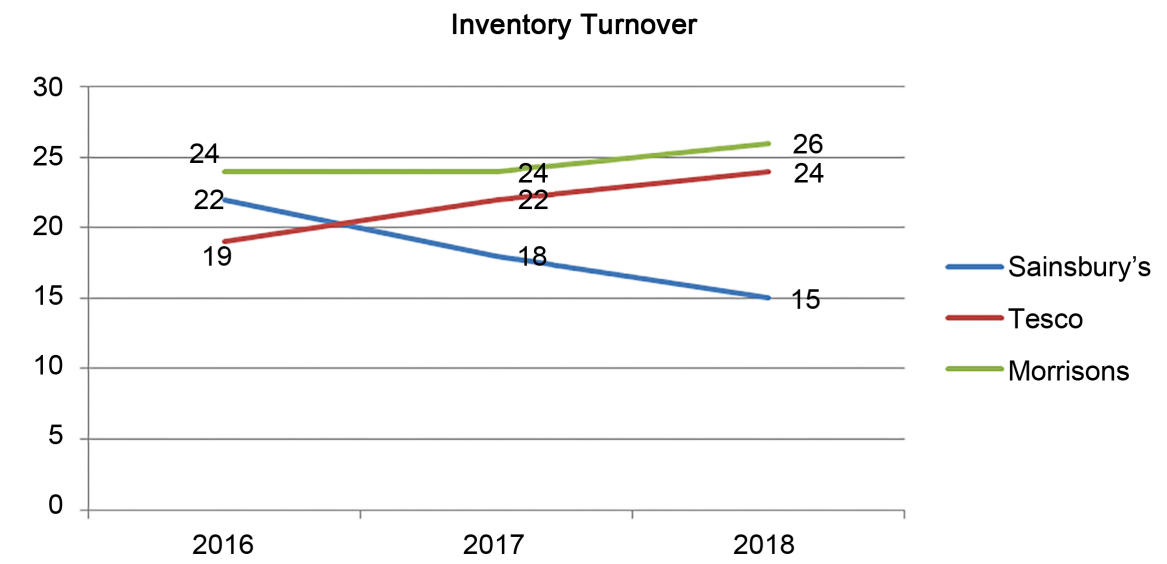

Figure 8. Inventory turnover of Sainsbury's compared with Tesco and Morrisons.

Table 1. Common size income statement.

\begin{tabular}{|c|c|c|c|c|c|c|c|c|c|}
\hline \multicolumn{10}{|c|}{ Common Size Income Statement } \\
\hline & \multicolumn{3}{|c|}{ Sainsbury's (\%) } & \multicolumn{3}{|c|}{ Morrisons (\%) } & \multicolumn{3}{|c|}{ Tesco (\%) } \\
\hline & 2016 & 2017 & 2018 & 2016 & 2017 & 2018 & 2016 & 2017 & 2018 \\
\hline Revenue & 100 & 100 & 100 & 100 & 100 & 100 & 100 & 100 & 100 \\
\hline $\begin{array}{l}\text { Cost of } \\
\text { sales }\end{array}$ & 93.8 & 93.8 & 93.4 & 96.2 & 96.3 & 96.3 & 94.8 & 94.6 & 94.1 \\
\hline $\begin{array}{l}\text { Gross } \\
\text { Profit }\end{array}$ & 6.2 & 6.2 & 6.6 & 3.8 & 3.7 & 3.7 & 5.2 & 5.4 & 5.9 \\
\hline $\begin{array}{l}\text { Operating } \\
\text { Expenses }^{\mathrm{a}}\end{array}$ & 3.6 & 4.6 & 5.0 & 2.9 & 1.5 & 1.7 & 3.4 & 3.1 & 3.1 \\
\hline $\begin{array}{l}\text { Operating } \\
\text { Income }\end{array}$ & 2.6 & 1.6 & 1.6 & 0.9 & 2.2 & 2.0 & 1.8 & 2.3 & 2.8 \\
\hline $\begin{array}{c}\text { Finance } \\
\text { Costs }\end{array}$ & 0.7 & 0.5 & 0.5 & 0.7 & 1.0 & 0.5 & 1.2 & 1.1 & 1.0 \\
\hline $\begin{array}{c}\text { Other } \\
\text { Income }^{\mathrm{b}}\end{array}$ & 0.4 & 0.8 & 0.3 & 1.1 & 0.8 & 0.7 & 0.0 & 0.1 & 0.2 \\
\hline $\begin{array}{l}\text { Income } \\
\text { before tax }\end{array}$ & 2.3 & 1.9 & 1.4 & 1.3 & 2.0 & 2.2 & 0.6 & 1.3 & 2.0 \\
\hline Taxation & 0.3 & 0.5 & 0.4 & 0.0 & 0.1 & 0.4 & 0.0 & 0.3 & 0.5 \\
\hline $\begin{array}{c}\text { Net } \\
\text { Income }\end{array}$ & 2.0 & 1.4 & 1.1 & 1.3 & 1.9 & 1.8 & 0.6 & 1.0 & 1.5 \\
\hline
\end{tabular}

${ }^{a}$ Administrative expenses. ${ }^{b}$ Includes income that are not from major operation, such as finance income, share of joint venture (after tax), profit/loss on disposal and other income.

According to its operating size, it is acceptable that Tesco has the highest finance costs. It can be seen that the finance costs of all companies is decreasing, but not from the reducing of borrowings. As for pretax profit margin calculated as profit before tax divided by sales, Sainsbury's is the best followed by Morrisons and then Tesco. However, Sainsbury's paid more tax than Morrisons, leading to a lower average net profit margin. ${ }^{5}$

${ }^{5}$ Net income divided by sales. 
In a nutshell, none of the companies show a large change in the usage of sales revenue, hence, there may not be changes in business model or cost structure. Cost of sales remains stable and most costly. In addition, Sainsbury's cost saving has much room for improvement in regards to its efficiency since no matter how strong the gross margin becomes, and Sainsbury's is still at a loss in comparison to its peer competitors.

\subsection{Trend Analysis}

Trend analysis is also known as base-year analysis. It helps investors spot what is driving the profit over a time, by setting a base year. The line items in base year are 100 per cent, and the trend can be shown by comparing following years' performance to base year.

In this trend analysis (Table 2), the base year is 2016, and the comparison years are 2017 and 2018. The first item, sales revenue, is increasing each year, which may have driven up cost of sales. This is good because the gross margin is increasing too. Nevertheless, larger selling activities could lead to a declining operating profit margin, indicating that the company is more likely to pay more to administrate its business. There is also a decline in pretax profit margin relative to 2016, even though the finance cost is less and less. This is probably caused by the declining of other income in Sainsbury's, whose majority finance income is losing over $£ 100$ m per year. In addition, in $2016 / 17$, Sainsbury's has completed acquiring some subsidiaries including Argos, which could be the reason of increasing sales. Meanwhile, it also brings more tax liabilities. Last but not least, the net profit is declining every year, which causes a weaker net profit margin.

Table 2. Comparison of income statement for Sainsbury's for years 2016, 2017 and 2018.

\begin{tabular}{|c|c|c|c|c|c|c|}
\hline & \multicolumn{6}{|c|}{ Comparative Income Statement } \\
\hline & \multicolumn{6}{|c|}{ For Years 2016, 2017, 2018} \\
\hline & \multicolumn{2}{|c|}{2016} & \multicolumn{2}{|c|}{2017} & \multicolumn{2}{|c|}{2018} \\
\hline & $\mathrm{Em}$ & $\%$ & $\mathfrak{E m}$ & $\%$ & $\mathrm{Em}$ & $\%$ \\
\hline Revenue & 23,506 & 100 & 26,224 & 111.6 & 28,456 & 121 \\
\hline Cost of sales & 22,050 & 100 & 24,590 & 111.5 & 26,574 & 120.5 \\
\hline Gross Profit & 1456 & 100 & 1634 & 112.2 & 1882 & 129.3 \\
\hline Operating Expense & 850 & 100 & 1207 & 142 & 1415 & 166.5 \\
\hline Operating Income & 606 & 100 & 427 & 70.5 & 467 & 77 \\
\hline Finance Costs & 167 & 100 & 136 & 81.4 & 140 & 83.8 \\
\hline Other Income & 109 & 100 & 212 & 194.5 & 82 & 75.2 \\
\hline Profit before Tax & 548 & 100 & 503 & 91.8 & 409 & 74.6 \\
\hline Taxation & 77 & 100 & 126 & 163.6 & 100 & 129.9 \\
\hline Net Income & 471 & 100 & 377 & 80 & 309 & 65.6 \\
\hline
\end{tabular}




\subsection{Segmental Financial Analysis}

Sainsbury's has three individual operating segments: retail, ${ }^{6}$ financial services ${ }^{7}$ and property investment. ${ }^{8}$ According to IFRS 8 in 2006, an operating segment is a component of a company, which is making profit and incurring expanses, and its operating results are available and regularly checked. Based on the data of segments separately, it enables us to compare the performance of each segment and understand the trend. In this report, the performance of main segments to that of group ${ }^{9}$ will be compared.

\subsubsection{Segment Margin}

Segment margin is calculated by dividing profit by revenue, which represents the ability of each segment of generating profits relative to its revenues. The results are as followed:

According to Figure 9, there is no big difference between the profit margins of retail segment and the whole group. They are basically at the same level. This means that the segment of retail does not affect the group's ability of generating profit. As for its second largest segment financial services, it has been declining each year though the profit margin is rather high.

\subsubsection{Return on Assets}

ROA measures how efficient a segment is at generating profit by using its assets. It is calculated as profit divided by assets. The results are shown in the following chart.

In Figure 10, the retail segment shows a higher ROA than the group, suggesting that the retail segment is better at generating earnings than the whole group. However, the segment of financial services has not utilized its asset efficiently, because the level of ROA is relatively lower compared to its amount of assets.

\subsubsection{Debt to Assets}

The debt to assets ratio measures how much the segment has borrowed to finance its assets. It provides us an insight of the segment's financial position. Banks tend to have a high debt to assets ratio, because they have to borrow large quantities which are further lent out in the form of loans.

As shown in Figure 11, it seems that the retail segment and the group have a similar debt to assets ratio. Therefore, it is likely that the group keeps investing most of its borrowings into its retail. Meanwhile, the financial services segment shows a faster increase in debts than that of assets. This probably results from the increasing number of loans issued by banks.

\footnotetext{
${ }^{6}$ Retail segment includes Sainsbury's supermarkets and convenience stores, General Merchandising \& Clothing, which is the major operating segment.

${ }^{7}$ Financial services are known as Sainsbury's Bank plc and Argos Financial Services entities.

${ }^{8}$ This includes underlying share of post-tax (loss)/profit from joint ventures.

${ }^{9}$ The profit figures used in calculations is underlying profit before tax, since there is no tax for single segment.
} 
Profit Margin (\%)

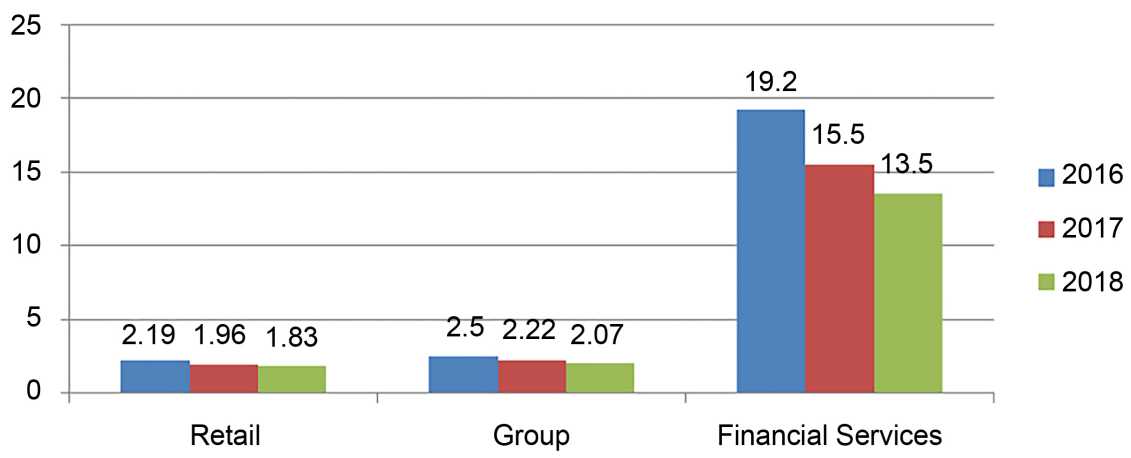

Figure 9. Profit margins from 2016-18 of Sainsbury's different sectors.

ROA (\%)

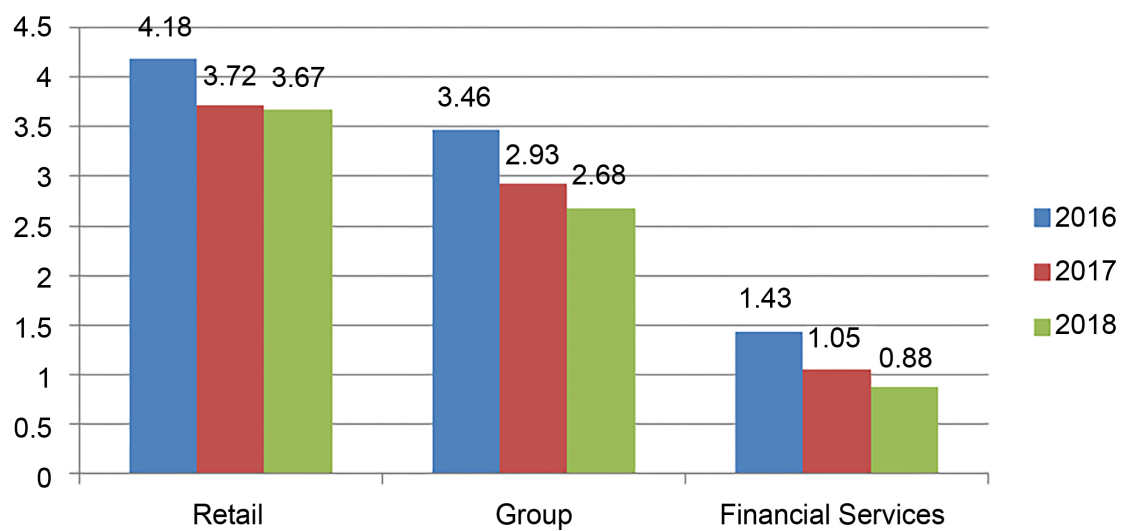

Figure 10. Comparison of ROA between sectors of Sainsbury's.

\section{Debt to assets}

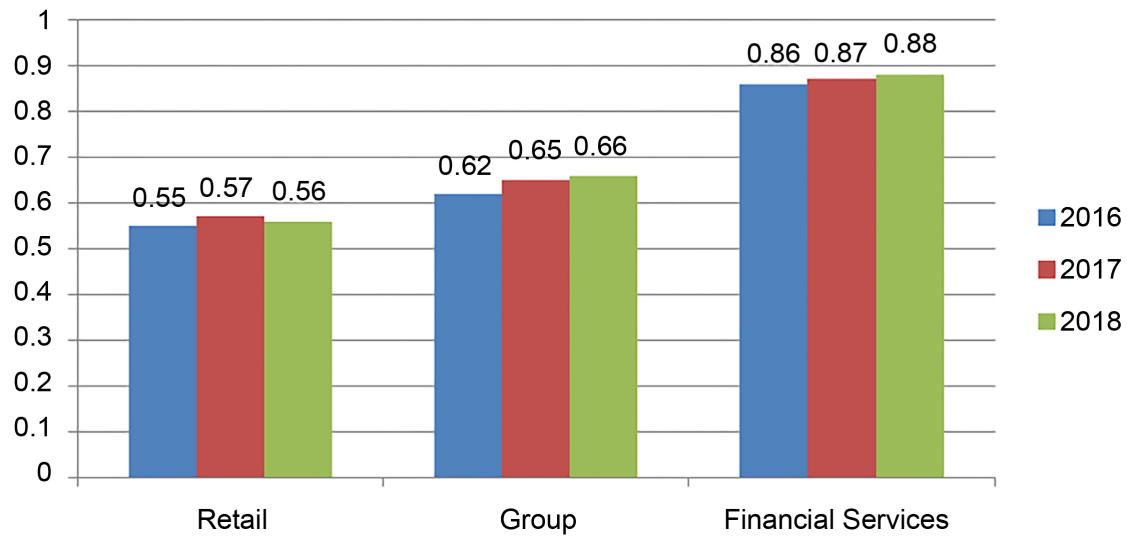

Figure 11. Comparison of debt to assets between the sectors of Sainsbury's.

\section{Conclusions and Recommendations}

To sum up, from the data of ratio analysis on the financial performance of $J$

Sainsbury plc, it can be concluded that in terms of profitability, liquidity, solvency 
and operational efficiency, Sainsbury's has performed the best in gross profit, but not well in ROA compared with its competitors; Sainsbury's has performed better respective to relative size with an increasing trend in the current ratio and quick ratio; Sainsbury's has a medium level of $\mathrm{D} / \mathrm{E}$ ratio in comparison to Tesco and Morrisons, and its debt to assets ratio remains at a relatively stable level; Sainsbury's sales show a decline with an increasing tendency in its total assets, and its inventory turnover has decreased. As for common size analysis, the three companies have not shown a large change in sales revenue, but Sainsbury's is still at a loss in comparison to its peer competitors. In regard to trend analysis of Sainsbury's between 2016 and 2018, it can be shown that its sales revenue and gross margin is increasing each year, while there is a decreasing trend in its operating profit, pretax profit margin, finance cost and net profit. As for segmental financial analysis of Sainsbury's, no significant difference between the profit margins of retail segments and the whole group has been found and its financial services segment is declining each year; the retail segment shows a higher ROA than the group and the financial services segment is not efficient in utilizing its asset; the retail segment and the group show a similar pattern in debt to assets ratio and the financial services segment shows a faster increase in debts than that of assets.

Based on the analyses of main indices, the financial performance of J Sainsbury plc should be further improved. The following recommendations concerning financial aspects, business environment and strategies are drawn to promote the financial performance of J Sainsbury plc. In terms of financial aspects, since net income has suffered a declining, and the operating expenses (administrative costs) increase much faster than the growth of gross profits, Sainsbury's should firstly rent more properties instead of purchasing, especially the action to be taken to allow the firm to terminate the contract and save money for the ownership of short-term lease in the future [17]. Secondly, the company can sell and lease back some less important fixed assets in order to allow the company to become the lessee who can still use the asset, and transfer the risk to the lessor (buyer). Thirdly, the management of administrative expenses should be more efficient to recruit more experienced managers who can observe the trend of the ratio, evaluate available suppliers more often to get more favorable discounts, and assess the bulk purchase discounts accurately, in case the company becomes involved with financial risks. Meanwhile, the purchasing department should keep and maintain efficient communications with the sales department, and conduct a system to establish the up to time supplies of and demands for each product effectively. Finally, it would be helpful to make more use of the customer loyalty Nectar card, to understand which products are selling fast and which products are less popular with customers.

In the case of business environment and strategies, the company should keep being a responsible retailer, employer and organization. In order to gain competitive advantages in a fierce and intense market like this, Sainsbury's should 
expand overseas, since there has been market saturation for UK retailers. Expanding into developing countries such as China and India is recommended. Furthermore, the quality of the products is important to customers, but since inflation has badly affected earnings, Sainsbury's has been pushed into an unfavorable situation with challenges from discounters such as Aldi and Lidl. Possibly, it will be helpful if the company can develop more different suppliers. Thirdly and then, Sainsbury's has been delivering diversified product ranges via different channels. Sainsbury's local, the convenience shop opening from early in the morning to the late of night in metropolitan area, is attracting more young customers who consume few products and have no time to cook. The range of pre-prepared food with higher quality is much wider than Tesco Express. Therefore, the company should develop more convenience stores, and enhance its facilities. Finally, a suggestion for Argos could be that the stocking system should be updated in a timely manner, and the instore screen should show which products are not available on a weekly basis. This would improve the customer experience by reducing frustration at finding the unavailable sought-after item they intended to purchase.

The present study conducted a financial ratio analysis of Sainsbury's between 2015 and 2018 in comparison with Tesco and Morrisons, pinpointing their strengths and weaknesses. However, there are limitations in the use of ratio analysis, and companies should take these limitations into account. First, ratio can only measure relative position and performance of a business, and companies should not fully depend on ratio but merely use it as an insight. Second, inflation can affect the values of ratio analysis of the company's financial performance. Due to inflation, the profit of the company may be overstated which will result in inaccuracy. Third, the information may be out-of-date so it does not reflect the real situation of the company, and the analysis of the financial statements reveals symptoms of such situations rather than the causes of it [18]. Future work can use a combination of ratio analysis and other methods such as the Accounting Rate of Return (ARR), Net Present Value (NPV) and Internal Rate of Return (IRR) to analyze the financial performance and make critical capital investment appraisal of these prominent companies to gain a more complete overview of their financial performance and economic condition.

\section{Conflicts of Interest}

The authors declare no conflicts of interest regarding the publication of this paper.

\section{References}

[1] Azeez, W. (2015) Capital Investment Appraisal in Retail Business Management: Sainsbury's as a Case Study. IOSR Journal of Business and Management, 17, 104-109.

[2] Moon, P. and Bates, K. (1993) Core Analysis in Strategic Performance Appraisal. Management Accounting Research, 4, 139-152.

https://doi.org/10.1006/mare.1993.1009 
[3] East, R. and Hogg, A. (1997) The Anatomy of Conquest: Tesco versus Sainsbury. The Journal of Brand Management, 5, 53-60. https://doi.org/10.1057/bm.1997.29

[4] Zhou, W. (2016) Quality and Usefulness of Financial Statements of Sainsbury. Global Market Information Guide, 16, 35.

[5] Adewuyi, A.W. (2016) Ratio Analysis of Tesco plc Financial Performance between 2010 and 2014 in Comparison to Both Sainsbury and Morrisons. Open Journal of Accounting, 5, 45-56. https://doi.org/10.4236/ojacct.2016.53006

[6] Investopedia (2018) Gross Margin.

https:/www.investopedia.com/terms/g/grossmargin.asp

[7] Investopedia (2018) Return on Assets-ROA.

https://www.investopedia.com/terms/r/returnonassets.asp

[8] Investopedia (2018) Current Ratio.

https://www.investopedia.com/terms/c/currentratio.asp

[9] Investopedia (2018) Quick Ratio. https://www.investopedia.com/terms/q/quickratio.asp

[10] Investopedia (2018) Solvency. https://www.investopedia.com/terms/s/solvency.asp

[11] Investopedia (2018) Financial Analysis: Solvency vs. Liquidity Ratios. https://www.investopedia.com/articles/investing/100313/financial-analysis-solvency -vs-liquidity-ratios.asp

[12] My Accounting Course (2018) Debt to Asset Ratio Formula. https://www.myaccountingcourse.com/financial-ratios/debt-to-asset-ratio

[13] Investopedia (2018) Asset Turnover Ratio. https://www.investopedia.com/terms/a/assetturnover.asp

[14] Fuhrmann, R. (2018) How to Calculate the Inventory Turnover Ratio? https://www.investopedia.com/ask/answers/070914/how-do-i-calculate-inventory-t urnover-ratio.asp

[15] Investopedia (2018) Inventory Turnover. https://www.investopedia.com/terms/i/inventoryturnover.asp

[16] Investopedia (2018) Common Size Income Statement. https://www.investopedia.com/terms/c/commonsizeincomestatement.asp

[17] Lewis, M. (2018) 13 Ways to Cut Administrative Overheard Costs in Your Business. https://www.moneycrashers.com/cut-administrative-overhead-costs/

[18] Berry, A. and Jarvis, R. (1997) Accounting in a Business Context. 3rd Edition, International Thomson Business Press, London. 